\title{
SPATIAL PLANNING EXPERIENCES FOR VULNERABILITY REDUCTION IN THE WILDLAND-URBAN INTERFACE IN MEDITERRANEAN EUROPEAN COUNTRIES
}

\author{
Luis Galiana-Martín ${ }^{1}$
}

Received 31 January 2017; Accepted 26 July 2017

\begin{abstract}
Expansion of the wildland-urban interface in countries in the European Mediterranean basin is increasing vulnerability to forest fires. Despite more effective extinction systems, this is still a growing problem. This article defends the importance of spatial planning (land-use and urban planning) and the need for systematic intervention to mitigate this wildfire risk. A critical review of the current situation, noting intervention focused on buildings and plots and insufficient action on intermediate spatial scales, is followed by the presentation of significant and relevant experiences in the European context.
\end{abstract}

Key words: wildfire, risk, mitigation, adaptation, fire management, land use planning, urban planning, urban sprawl

Resumen: La expansión de la interfaz urbano forestal en los países de la cuenca mediterránea europea está provocando un aumento de la vulnerabilidad frente a los incendios forestales. A pesar del aumento de la eficacia de los sistemas de extinción el problema no deja de agravarse. En el artículo se defiende el protagonismo que debe corresponder a la planificación espacial (ordenación del territorio, urbanismo) en la reducción del problema, ante la necesidad de intervenir de una manera sistémica sobre el mismo. Tras una revisión crítica del estado de la cuestión, donde se observa una intervención centrada en las estructuras edificadas y la parcela junto con un déficit de actuación en las escalas espaciales intermedias, se presentan experiencias significativas en el ámbito europeo.

Palabras clave: incendios forestales, mitigación, adaptación, gestión de incendios forestales, planificación territorial, planificación urbana, urbanización dispersa.

\section{Introduction}

The growing risk of forest fires and the substantial material losses related to them cause mounting public alarm in the European Mediterranean area. The increasingly serious and complex nature of these episodes of environmental instability has been related to various socio-spatial dynamics,

\footnotetext{
${ }^{1}$ PhD Luis Galiana-Martín, University Lecturer, Department of Geography, Universidad Autónoma de Madrid, Avenida Francisco Tomás y Valiente 1, E-28049 Madrid, Spain, e-mail: luis.galiana@uam.es
} 
including rural depopulation, increased urban sprawl and/or specific land-use land-cover (LULC) changes (Moritz et al. 2014). The close relationship between the evolving risk of forest fire and spatial dynamics explains the shift in the main challenges in risk-management of these events in recent decades.

Studies of fire activity trends in some European countries highlight existing discontinuities which suggest the role played by various factors with varying importance at each point in time in this evolution (Moreno et al. 2014). In the second half of the $20^{\text {th }}$ century, fuel accumulation from abandoned agricultural activity, and the progressive growth of natural vegetation resulting from both natural regeneration and repopulation, increased the landscape fire-hazard due to the spatial continuity of highly flammable vegetation over large areas (Moreira et al. 2011). The result of these changes was an increase in wildfires, while deforestation and densification processes turned into more significant LULC changes, further increasing the fire-hazard (Viedma et al. 2015). Over the last 25 years, the factors explaining the process of agricultural abandonment have varied and this process is increasingly affecting areas near populated settlements (Bakker \& Veldkamp 2012). Added to this, the ongoing expansion of urbanisation is characterised by high spatial dispersion (EEA 2016), and there is clear evidence of far more wildland-urban interface (WUI) scenarios, and therefore a higher fire risk (Martínez et al. 2009). As a result, the largest area currently burned by wildfires in the European Mediterranean zone coincides with the most densely populated areas (Moritz et al. 2014).

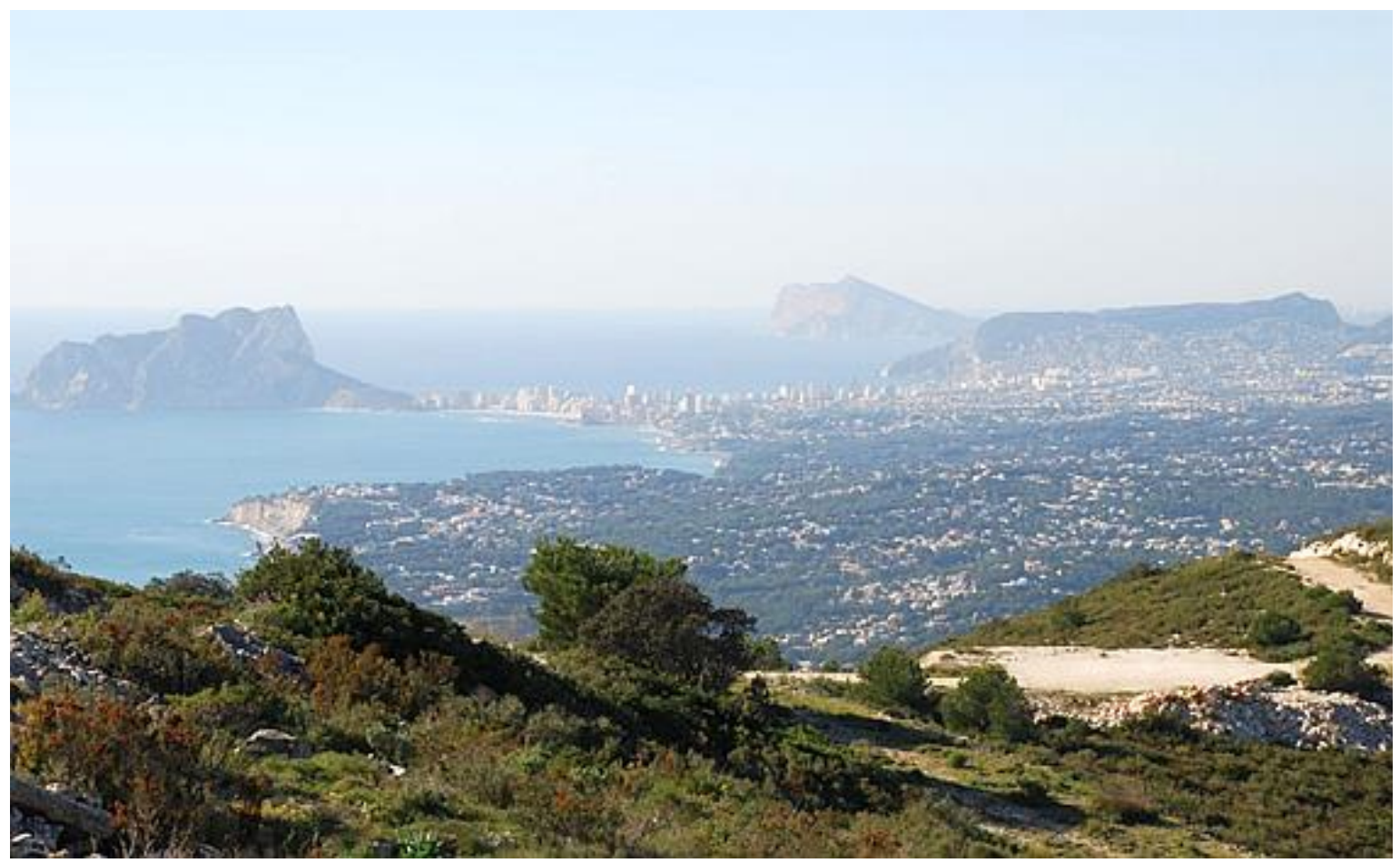

Fig 1. Wildland-urban interface (WUI) progression on the Mediterranean coast (Alicante, Spain).

The main focus of attention is therefore shifting from the forested/agricultural frontier, with the crisis of the traditional agricultural model triggering intense changes in fire regimes, to the periurban interface, with the growing importance of fires which affect or may affect urban built-up areas (Galiana 2012). This process is especially intense in the European Mediterranean area, an important demographic hub with a high demand for residential provision, especially in urban and coastal areas where potential inhabitants are absorbed primarily into peri-urban and nearby rural zones (Fig. 1 and 2). The result, just as in California or Australia, is that the vulnerability of residential properties to wildfires merits widespread attention in policy-making, the media and scientific literature, with potential, increasing severe fire conditions in view of climate change and projected housing developments (Syphard et al. 2013). 


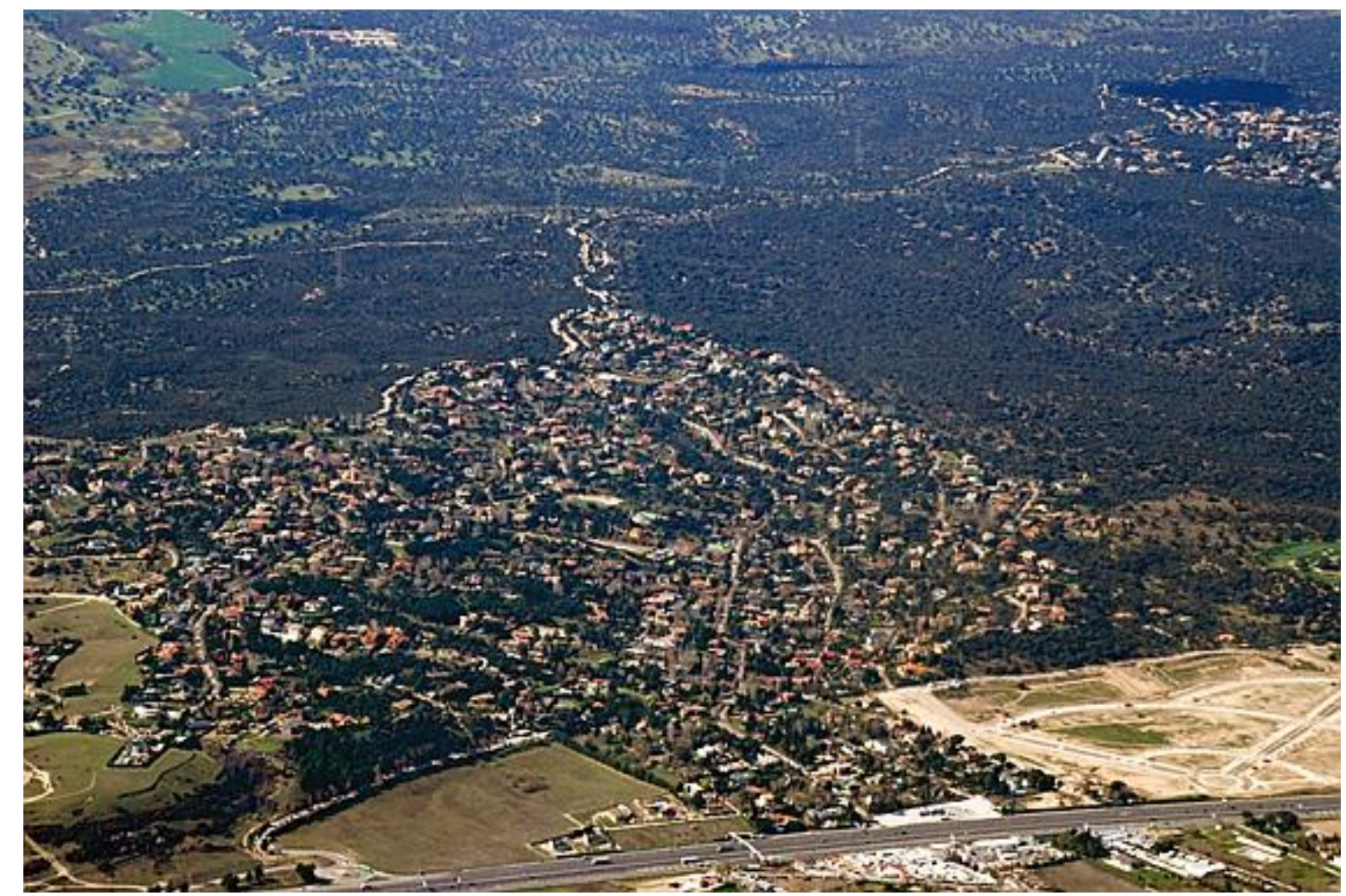

Fig 2. WUI progression in metropolitan areas (Madrid, Spain).

It is important here to point out how these urban development processes operate within a context of fire risk denial, both in public planning and individual human behaviour, with negative results for risk management. The attitudes adopted to the environmental challenge posed by the increase in urban sprawl are paradoxical. There is widespread consensus that wildfires are the main evidence of the environmental instability provoked by this type of spatial development in the Mediterranean area. Nevertheless, the discourse on low density urban development processes, and the perception that they are one of the main causes of non-sustainability, normally cites various negative factors (economic and functional inefficiency, social segregation, negative environmental impact (e.g., Indovina 2007) but does not mention how they contribute to increased vulnerability to wildfire risk.

This presents a territorial problem which is approached in purely sectorial planning terms (forestry, urban development, civil protection, and especially environmental) and with a preferred action scope on a local scale. This is a delicate, complex question which should be addressed on various scales (land plot, urban planning, municipal area or forest-based, depending on the logical, dynamic contexts pertaining in each of these), adopting an integrated or global approach (Fischer et al. 2016). This territorial, multi-scale approach is particularly difficult within an official framework which is markedly sectorial, and where the scope for action is almost exclusively on a local scale.

Our working hypothesis is that, in the current situation, reducing vulnerability to fires requires decisive action to solve the problem of forest interfaces and that this intervention should come about within the framework of land-use planning in a multi-scale approach. Traditional fire-risk reduction focusing on fire suppression continues to dominate fire management, using evergreater financial resources, but has not managed to reduce the scope of the problem. This article aims to contribute to the current fire management debate from a global, territorial viewpoint.

\section{Reducing vulnerability in the wildland-urban interface. Current situation and new perspectives}

Wildfire management to date has been almost exclusively reactive. The politicians and technicians responsible prefer to prioritise short term objectives, in response to growing social pressure. This means that efforts focus on extinction, developing extremely sophisticated, 
efficient techniques to ensure the rapid suppression of most fire episodes. However, the problem is not solved: some fires overwhelm the response capacity of the extinction systems, causing increasingly important and complex episodes. For this reason, in scientific and technical circles there is an increasing awareness that efforts should be redirected to systemic influences on fire risk (land-use planning, climate change, active resource management) (Smith et al. 2016) to achieve a sustainable coexistence with fire.

In terms of this co-existence with fire, urban growth is clearly non-compatible with forest fires in some environments. Faced with the evidence that past land-use decision making allowed large scale house building in fire-prone areas (Pincetl et al. 2008), the need is emerging for an urgent, serious reassessment of urban planning and building in fire risk areas to halt further expansion of this problem (Moritz \& Stephens 2008; Moritz et al. 2014). Careful consideration should be given in land-use planning to the relationship between population settlements and the risk of forest fires. An urgent approach is essential to both the problem of the placing of new urban developments and to their formal shaping to reduce their risk exposure. But the aim of reducing vulnerability should also include how to deal with the status quo, taking appropriate action to deal with forest fuels in interface zones and preparing these communities to co-exist with the implicit risk (Syphard et al. 2013).

\subsection{Management strategies for WUI based in land use controls and fuel load reduction}

In recent years, the idea that land-use planning at different scales must respond to important future wildfire challenges has gained support in an urban development model marked by growing dispersion and the possible negative effects of climate change. Analysis of the different viewpoints shows that the concepts of resilience, vulnerability and risk predominate in the public policy debate in many countries, in a scenario dominated by the critical role of future disasters directly related to climate change (flooding, drought, wildfires) (Hughes \& Mercer, 2009).

A future forest fire scenario is envisaged where the combination of higher temperatures, lower precipitation, increased evaporation and less runoff will lead to an increased number of days with extreme fire risk, requiring different policies from those in place to date (Buxton et al. 2011). In this context, Australia (the world region most affected by forest fires) is a clear example of the importance given recently to spatial planning, facilitating adaptation to climate change, particularly in preparation for the increased probability and virulence of extreme climatic events (Bond \& Mercer 2014).

The special significance of climate change for spatial planning and the need to adopt strategies to mitigate its long-term effects, based on land-use planning (especially more sensible location of houses and other urban developments), coincide with enhanced approaches to the concept of green infrastructure. The introduction of new principles and values in the definition of green infrastructure (understood as land exempt from urban development processes), makes risk prevention an essential conformation and management criterion, together with ecological connectivity through protected agricultural and forest areas and landscape preservation.

With this approach, an analysis of practices shows how mandatory instruments are set in motion in reactive response to situations of extraordinary emergency. Thus, for example, after the serious events in summer 2009, the state of Victoria acknowledged the need for a mandatory plan to deal with fire risk (identified in the Victorian Bushfire Royal Commission report), which led to the introduction of new planning scheme requirements in 2011 (Holland et al. 2013). Similarly, the catastrophic fire event in the Var region (French Mediterranean coast) in 2003 was followed by the exceptional interest shown by the national government in developing plans to restrict urban development in high risk areas, reflected in Plans de Prévention des risques d'incendie de forêt (an environmentally based document which takes legal precedence over local urban planning schemes) (Bouisset 2011, Fig. 3). 


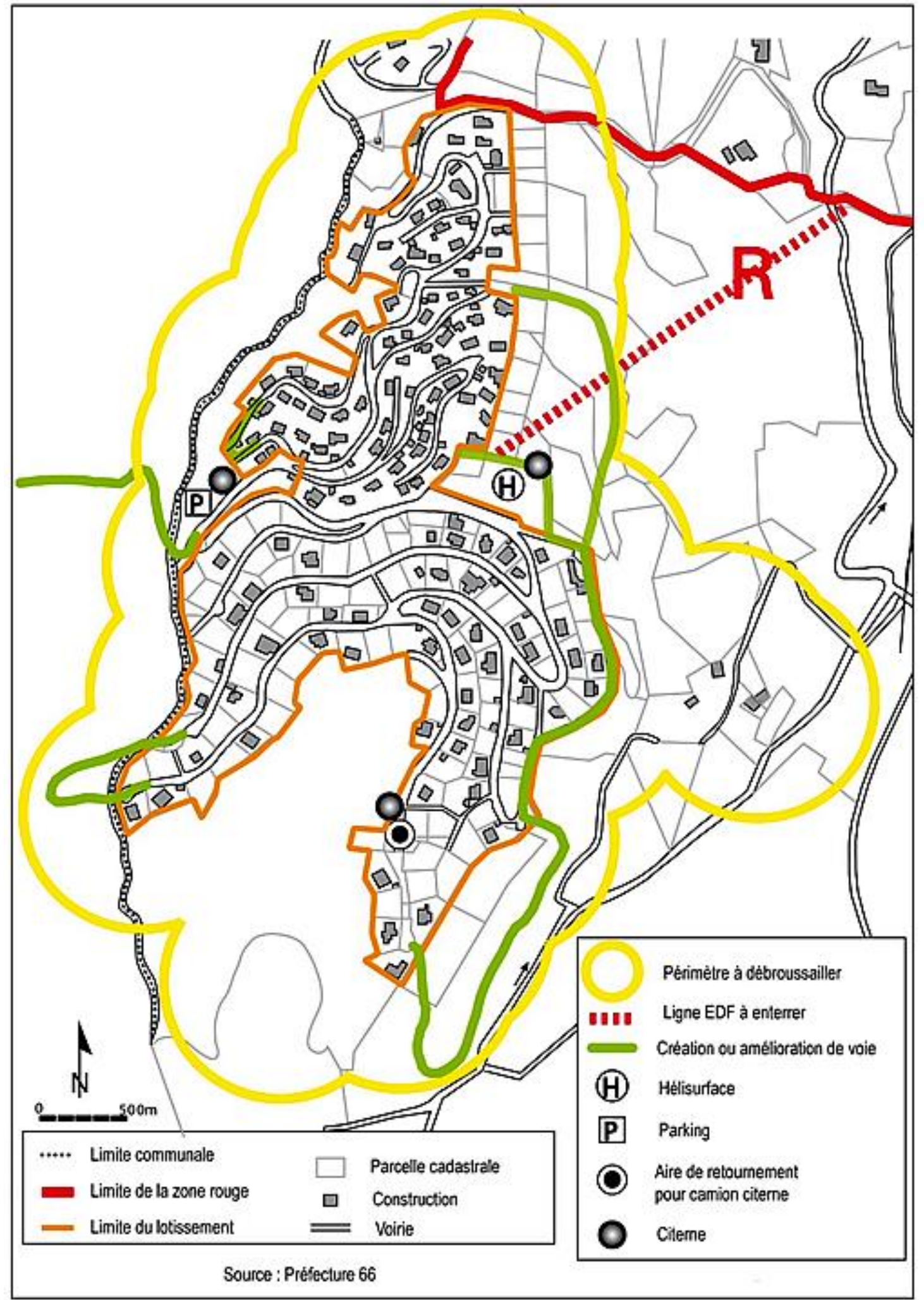

Fig 3. Example of mitigation actions for urban development in forests (Bouisset 2011).

In short, based on the sustainability discourse and the need to adapt to climate change, and in reaction to the succession of extraordinary events with high social impact, a new wildfire prevention perspective is emerging. This is reflected in new land-use planning and management measures promoting passive protection against wildfires in WUls based on land use controls, particularly restrictions and limitations on new urban developments. 


\subsubsection{Dealing with interface situations based on risk/vulnerability assessment}

Just as in other areas of risk management, the management of wildfire risk begins with an assessment of wildfire event probability, and the susceptibility of highly valued resources and assets to wildfire (Calkin et al. 2014). This assessment can be carried out from different standpoints (risk, hazard, vulnerability).

Studies of wildfire risk at the WUI often calculate the statistical relationship between ignition and WUI characteristics (building density, distance to urban area and anthropogenic land use). Haight et al. examined the relative risk of severe wildfire at the WUI based on a combination of fuels, historic fire regimes, and housing density (Haight et al. 2004). In contrast, studies of WUI wildfire hazard typically model potential wildfire intensity or exposure based on factors such as vegetation, topography and housing density. To determine the spatial distribution of potential wildfire risk, different solutions have been proposed to model critical hazard and risk variables (validated with the regional historical wildfire pattern). For example, in the Lein \& Stump approach, wildfire potential is the result of ignition potential based on flammability and exposure to ignition vectors calculated from a conceptual model of significant variables associated with the threat of wildfire. The factors used in the conceptual model were solar radiation, topographic humidity, fuel, population density and distance from roads. Using this model, planners and policy makers can develop more effective strategies to manage ex-urban development within the WUI and reduce vulnerability to wildfire hazard (Lein \& Stump 2009).

Current research on the spatial dimension of risk tends to prefer an approach based on analysis of hazard-related vulnerability. Vulnerability models based on operational objectives consider: a) vulnerability factors (awareness); b) more effective preventive actions using a territorial approach adapted to the local context (Galiana-Martin \& Karlsson 2012). Hierarchical and thematic mapping enables an integrated approach to the problem, and the disaggregation and spatial representation of the main factors involved. Defining these factors is of maximum importance and must be carried out using operational values to set up prevention and suppression tasks (Galiana-Martin and Karlsson 2012).

However, these landscape-scale assessments cannot be reliably applied to individual buildings or neighbourhoods (Platt 2014). This is primarily because wildfire hazard for structures is mainly determined by local rather than by landscape factors (Cohen 2010).

\subsubsection{Reducing vulnerability: ex ante and ex post}

Vulnerability reduction can be divided into two types depending on when it is actioned. The first type is ex ante action to avoid fire spread: the aim here is to leave the most exposed zones undeveloped and, in general terms, to restrict development patterns in risk-prone areas. In fact, this means devising a common sense territorial model. The second type is ex post action, adapting the existing situation or status quo to reduce vulnerability in these areas, acting on the fuel load (in both the forest and in building materials).

The most common management strategy is to control or reduce fuel, to solve the problem. Two main actions can be taken: fuel reduction in the forest surrounding the WUI to provide a 'defensible space' or safe protection opportunity for homes during a wildfire; and action taken by homeowners to reduce the flammability of their property and its immediate surroundings, and ensure accessibility for firefighters to provide further protection (Kennedy \& Johnson 2014, Fig. 4 and 5).

The two main objectives of fuel risk treatment are to reduce wildfire intensity and severity within treated areas, and to reduce the probability of fire occurrence beyond treated areas by limiting fire spread rates and/or enhancing suppression effectiveness. The dimensions are normally determined through experimental studies, depending on the environmental characteristics and the protection objective, or with statistical analysis of past fire patterns to predict and map the likelihood of wildfires spreading to the urban interface (Price et al. 2015). Cost-effective simulation models applied to various preventive treatments are useful tools when adopting appropriate measures to mitigate fire effects in built-up areas (Stockmann et al. 2010). 


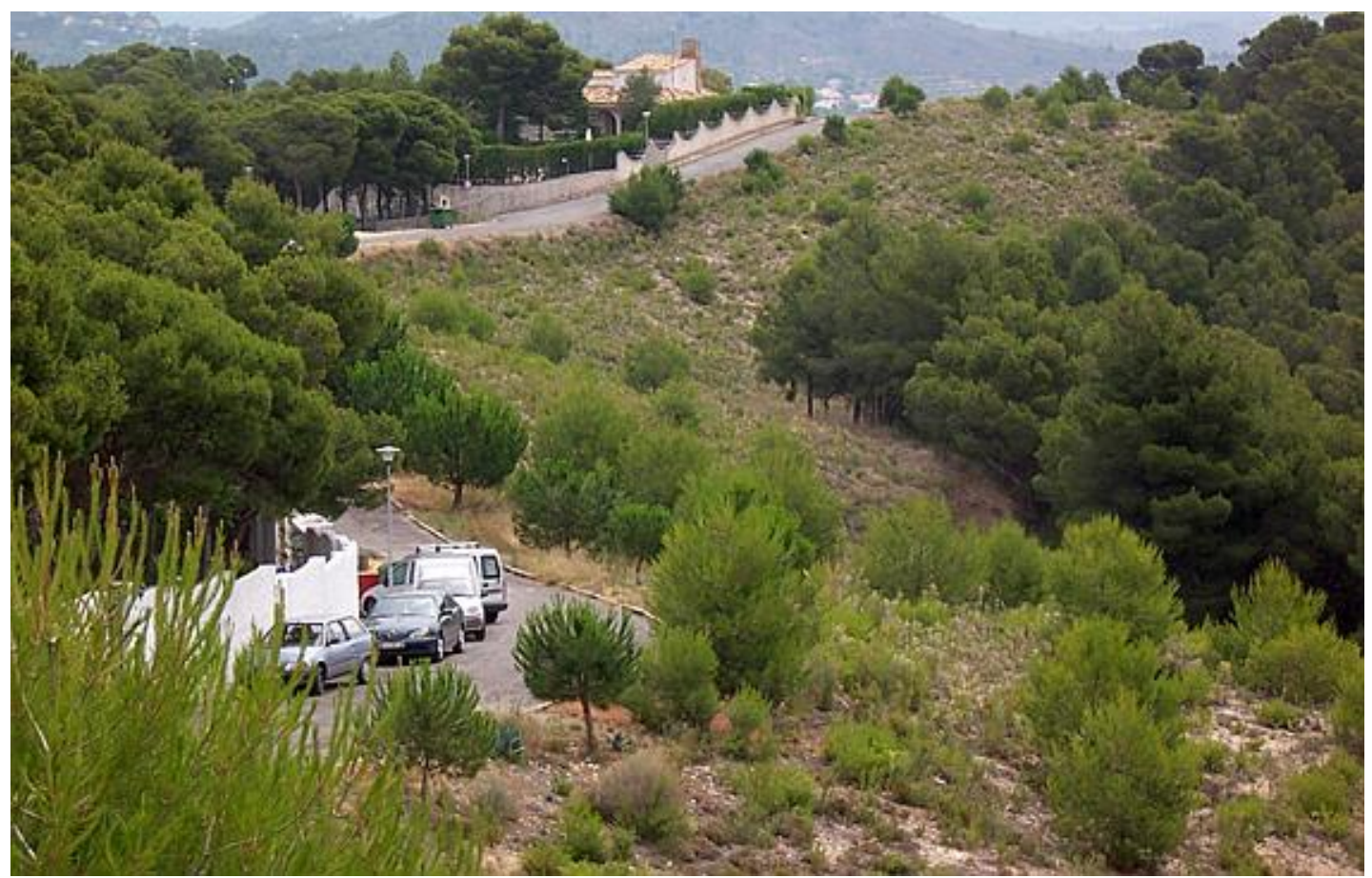

Fig 4. Forest fuel reduction in urban development perimeter strip (Sierra Calderona, Valencia, Spain).

Various approaches have been used to investigate the optimal location for fuel treatment. Highrisk areas, identified by a combination of high fire hazard, predicted extreme fire behaviour and high ignition risk, have been used to prioritise sub-watersheds for fuel treatment and facilitate wildfire suppression (Bar Massada et al. 2011, Castillo 2012, Kennedy and Johnson 2014). However, these research methods are often complicated and require large-scale parameterisation and validation data (Elia et al. 2014).

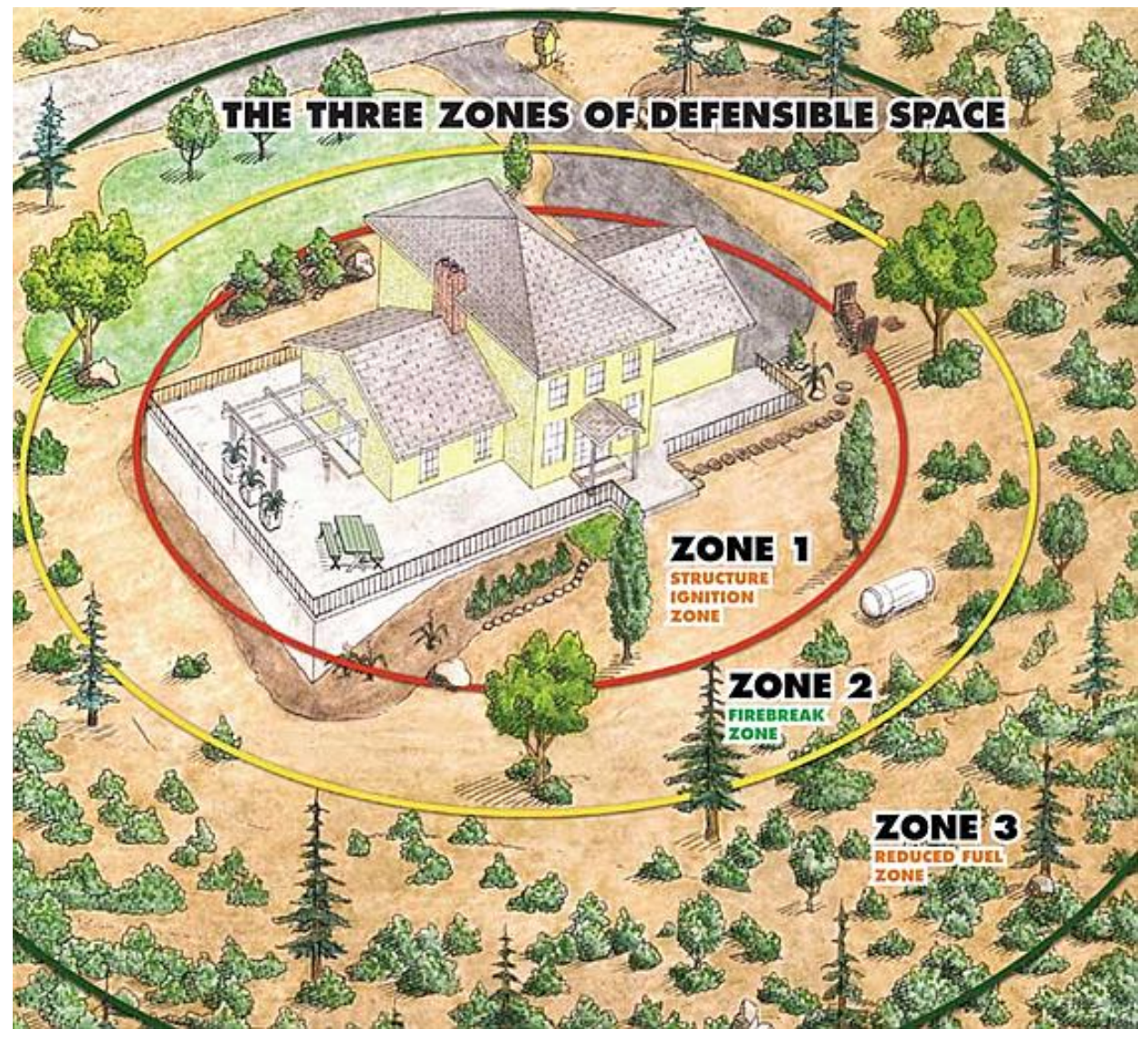

Fig 5. The Home Ignition Zone. Source: http://firewisemaderacounty.org/harden-your-home/ 
The consensus is that significant investment is required to manage fuels and prevent ignition on a large landscape scale, and that the resources needed are always limited. Lafortezza et al. (2015) proposed an indicator to prioritise management intervention by integrating social, economic and ecological factors, applied to a case study in southern Italy. Their results highlight the need to prioritise fuel removal in densely populated landscapes, thus maximising the ratio of number of inhabitants exposed to wildfire suppression/ euros spent on fuel removal.

In North America, expenditure on reducing wildfire risk has increased significantly since 2001, and is mainly spent on reducing WUI-related fuel. The US LANDFIRE program is intended to identify and prioritise high-risk areas; however, final decisions are largely dependent on 'cronyism and politics-as-usual' (Colburn 2008). In fact, there is no standard method to identify and prioritise communities according to risk level. There are different approaches to defining where and what type of forest areas are eligible for fuel removal in terms of fire suppression. Methods to allocate fuel treatments usually deal with a range of criteria (fuel load, landscape patterns, house density, road density, population density) (Elia et al. 2014). On the other hand, there is only a limited understanding of how these fuel treatments affect the strategic protection of communities from wildfire in interface areas.

In Europe, the most common approach is fuel reduction, with a mandatory requirement to clear a security perimeter of variable width around urban developments to reduce wildfire intensity. The relevant legal provisions in Spain include forestry regulations, Building Codes, or wildfire regulations (Galiana 2012) (Box 2, Fig. 3). Similar measures are found in French, Portuguese or Italian forestry regulations, which define a mandatory cleared contact zone. In the Mediterranean region, fuel reduction based on treatment of built structures and their immediate surroundings reveals limited critical criteria in the imported approach to the problem.

In conclusion, reducing vulnerability by treating built structures and the surrounding areas involves an imported and simply adapted approach, with little critical consideration. This leads to an ongoing focus on structure ignition rather than on the complexity this implies for suppression: this means that intervention strategies are essentially conditioned by the priority given to buildings, simultaneous defence of multiple dwellings and mass evacuation.

\section{WUI management strategies. Examples of good practice}

The evolution of management strategies in the US and Australia, where for several decades WUIs have been considered priority areas for wildfire prevention and readiness, is an indicator of future management needs for these areas in the Mediterranean region. Fuel reduction in forested land adjacent to built-up areas and emergency evacuation are priorities in prevention policy (Haight et al. 2004). The choice of risk mitigation options is based on defining appropriate wildfire management objectives, and how risk mitigation options differ realistically in terms of cost, likely effectiveness, and the appropriate identification of who is responsible (Calkin et al. 2014).

Cutting down home losses has traditionally been a priority in WUI management. A significant proportion of management activity addresses home ignition conditions. However, perception of WUI fire disasters as a wildfire control problem rather than a home ignition problem is gradually gaining ground. From this viewpoint, reducing the risk of residential property loss should not only include increased resistance to ignition, but also reduced wildfire occurrence, size and intensity, or reduced human settlement in fire-prone areas (Calkin et al. 2014). The analysis of structures affected by wildfire in the past offers interesting conclusions on how to approach risk reduction in future residential developments (Syphard et al. 2013). This is no easy task: the rapidly evolving risk levels detected in land areas traditionally used for residential development require planning which can adapt iteratively to risks (Bardsley et al. 2015).

\subsection{The need for a spatial planning approach}

If we consider WUls as the result of a process of scattered urban development and the progression of forested areas, then the profile of adaptable planning is intervention to prevent the spread of this process: the goal is to reduce urban development in the areas of highest exposure and, in general terms, to establish restrictions and suitable development patterns in 
areas at risk. Imposing building restrictions is the most effective way to limit the scope of the problem, whether this means a direct ban on construction in high risk areas, or drawing up building specifications to ensure defence if wildfires occur (including e.g., an adequate road network or the use of specific materials).

The limits to property rights involved mean this approach requires sound arguments, as this is the only way to legalise the process. These arguments are usually formulated from sector-based considerations of the problem (forestry and environmental regulations; and to a lesser extent civil protection).

These restrictions on urban development and building must be carried out at different scales, ranging from intermediate or supra-local, local or municipal urban development, down to the building plot and the building itself. A widespread approach suggests that, while being recognised as unavoidable that a small number of events will develop into particularly large wildland fires exceeding suppression capacity, disaster prevention in wildland-urban interfaces must focus on reducing the problem severity by reducing the ignition potential of built structures (Mell et al., 2010). Thus, the main scale of intervention would be the Home Ignition Zone, i.e. the buildings themselves and their immediate surroundings. More recent, broader-scale approaches, which tend to ban certain uses in particularly sensitive wildfire-prone areas, are finding it difficult to gain ground.

\subsubsection{Intermediate and local scale spatial planning}

A supralocal approach is required to this problem which clearly exceeds municipal boundaries, but this comes into conflict with the regulatory framework of spatial planning, whose preferential (and sometimes only) scope of application for mandatory regulations is on the local/municipal scale. However, a consistent prevention policy requires the overall integration of the forests and urban areas affected to achieve coherence, which cannot result from a purely municipal approach.

Thus, planning at a supralocal level must move to adopting a strategic perspective to detect and regulate processes with the most relevant implications. The planning role should be to rationalise these processes, coordinating space and time-bound risk management at this level (Galiana, 2012). In this way, formulating aims and objectives defined from diagnosis on an intermediate scale would be reflected in the regulatory framework of local planning documents approved for that area. There are many examples of assessment and awareness documents drawn up at this scale including e.g. in France, the Schéma de Cohérence Territoriale, or Plan Départemental de Protection des Forêts contre les Incendies.

In the state of Victoria (Australia), the Victorian Planning Provisions (VPP) advance this coherence. The mitigation strategy in high risk areas, identified by the Country Fire Authority (CFA), is implemented by establishing restrictive zoning: the Wildfire Management Overlay (WMO), or from 2011 the Bushfire Management Overlay (BMO). The WMO operated as a regulatory mechanism in local planning schemes, to provide a decision-making tool for the concession of town planning and building authorisation. Whether or not the protection objectives were met in licence applications, passed by the CFA, was assessed by monitoring a series of specific criteria for the placing and design of the housing, water points, vegetation management and access. It was applied until 2009 in a discretional and permissive approach, provoking numerous lawsuits and inconsistent decisions, and has not prevented increased housing development in high-risk zones (Buxton et al. 2011). Nevertheless, its influence on the mitigation of the damage caused by the 2009 fires should not be underrated: the housing built within this regulation framework presents a considerably lower percentage of houses destroyed than in the high-risk area affected as a whole (Holland et al., 2013). However, the extreme events of 2009 prompted its amendment in 2011, prioritising human lives over any other criteria and adopting a precautionary approach to new developments. The WMO was replaced by the BMO, much more normative and binding in operation, which continues to apply fundamental criteria of placing and design, water points, access routes, etc. It establishes the concept of 'defensible space', an area surrounding the house which allows active defence by the occupants and fire services (Holland et al., 2013). 
The local/municipal scale is the main scope of application for provision of mandatory and executive decisions on urban development processes. The first measure taken at municipal level should be to identify risk areas clearly and define the most appropriate sectors for new developments. Planning in these areas must address a wide, complex range of issues (growth predictions, risks affecting the territory, preserving farmland), which may lead to the choice of forestry sectors as the most appropriate response to the demand for new housing, stating that these areas are highly regarded in terms of living standards, especially for low-density building developments, influences this choice.

Identifying risk areas must certainly be based on zoning in sectorial and environmental planning, and highlight the high risk involved in building in those areas, banning construction or setting strict building conditions. While other types of disaster, such as flooding, are usually taken into account in urban planning documents through well-defined protocols, wildfire risk is not. In zones badly affected by fires and intense urban sprawl processes (e.g. peri-urban zones in SE Australia), an important debate is underway on whether housing development should be banned or restricted in high risk areas (Bond \& Mercer 2014), but even in these cases a total ban on building is exceptional when based only on risk assessment. Simulations of the influence of restrictive land use policy on wildfire risk for the WUI clearly show the positive effects expected (Paveglio et al. 2013); this is also true for land conservation purchase practices on a county scale (Butsic et al. 2017).

An alternative approach to the problem, not based on strict zoning but on assuming certain criteria for urban development, enabling better adaptation to the fire regime, is being trialled in the department of Var, on the French Mediterranean coast. The Conséil d'Aménagement, d'Urbanisme et de l'Environnement (CAUE) leads a process of reflection and recommendations to municipal authorities and spatial managers: these include proposing compact urban developments to allow reduced contact areas between residential sectors and vegetation, and preserving agricultural buffer zones (Lévy \& Broussus 2007). Similar conclusions have been obtained using models of different growth types (infill, expansion, leapfrog) (Syphard et al. 2013) (Fig. 6).
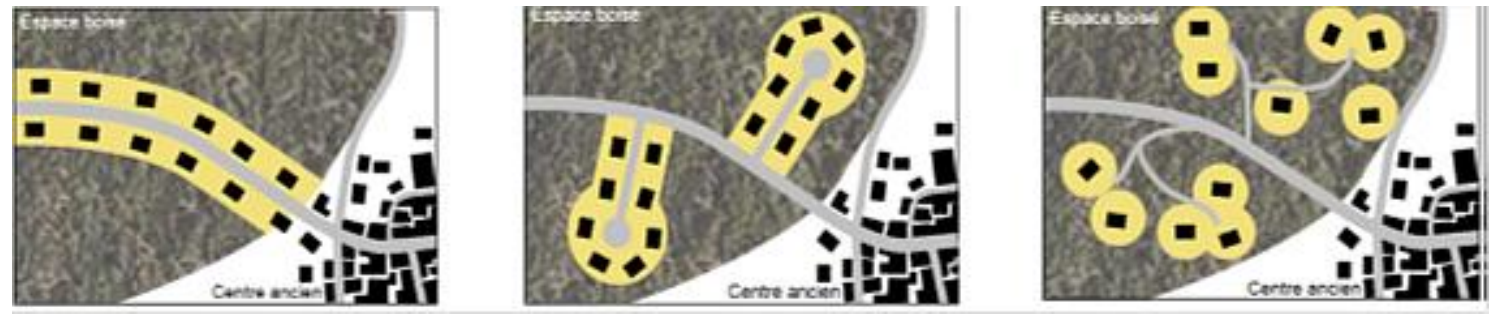

Fig 6. Urban designs to be avoided: several characteristic forms of urban sprawl should be avoided to reduce contact zones between houses and vegetation (Lévy and Broussus 2007).

The scarce examples of mandatory planning include the French Plans de prévention des risques naturels (Risques d'incendies de forêt) (PPRIF). These are specific regulatory measures reflected in the 1995 Code de l'Environnement, allowing demarcation of affected areas and prescribing prevention measures for them. These are the standard reference documents for considering risks in local planning, as they are mandatory, take precedence over other planning types, and must be annexed to the appropriate urban plan at municipal level (Plan Local d'Urbanisme). The Albères Massif in Eastern Pyrenees (France), characterised by house developments in highly vulnerable forest, was the scenario for the roll-out of these mechanisms. The PPRIF put a stop to the increasing density of these developments, although there were significant complaints from local people and municipal authorities (Bouisset 2011) (Fig. 4).

\subsubsection{Urban development and plot treatment}

Intervention on an urban development scale has occurred since the earliest transformation of rural into urban areas, and is essential to organise residential areas at the forest interface with planning adapted to existing hazards, to reduce risk to acceptable levels. Despite the generally 
acknowledged significance of urban planning and design in terms of fire suppression, it is remarkable how little research has been done into the problems of access roads and the morphology of urban developments, compared with plot-scale intervention in the home ignition zone. There is only a well-established tradition of this research in the US, with relevant conclusions translated into regulations or guidelines (Bond \& Mercer 2014), especially in the context of evacuation route capacity and the need to limit residential building (Cova 2005, Cova et al. 2013).

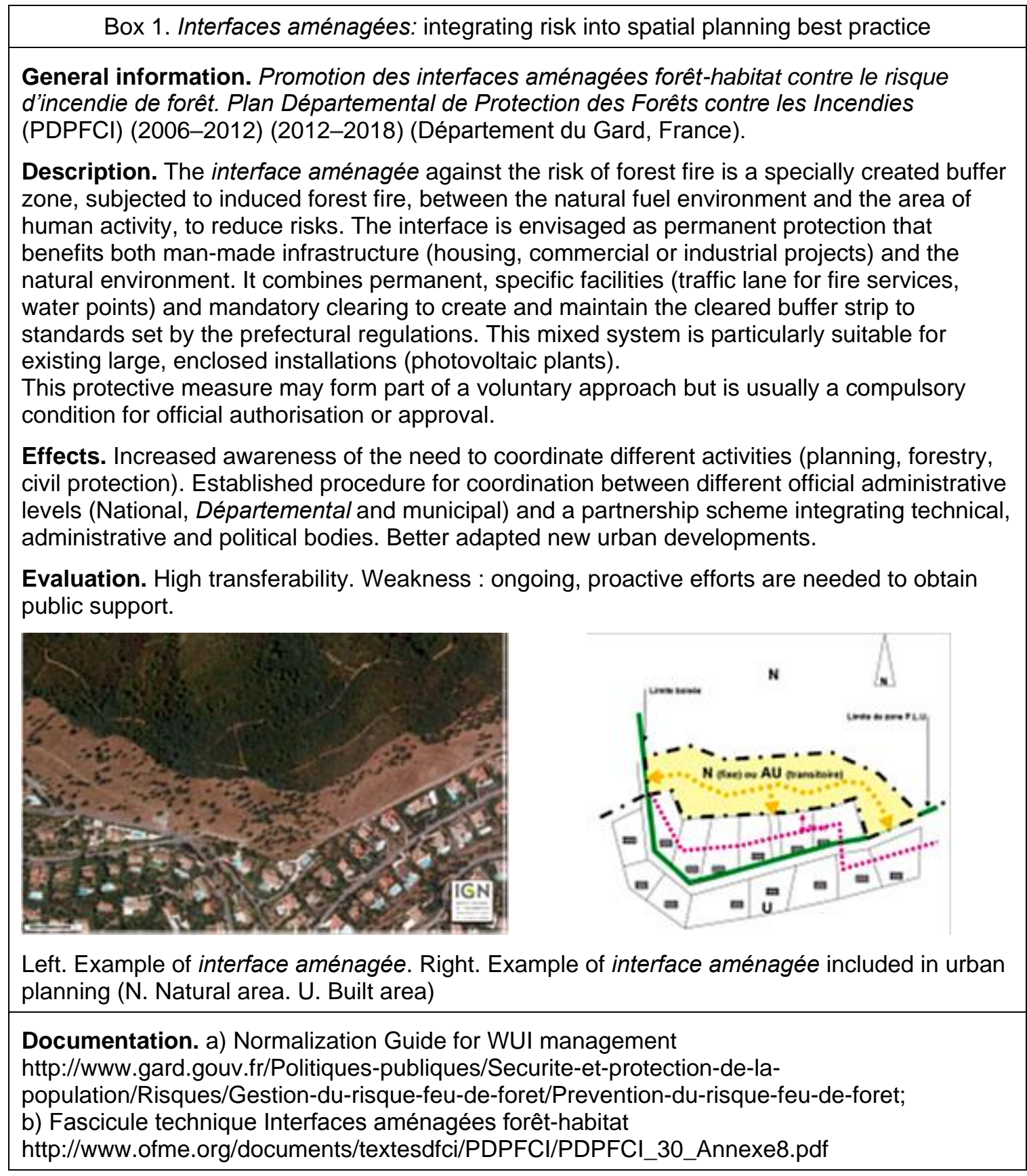

Most guides and recommendations, whether prescriptive or indicative, include design criteria for vegetation management (in buffer areas, at development and plot scales), road design and emergency access routes (perimeter roads, turn radius, slopes), and water supply; and they also include the need to consider urban developments on a landscape scale, taking advantages of improved defence opportunities.

In general, the standard urban pattern is not questioned (low-density, single-unit residential developments), and there are few claims for other, better-adapted design solutions: urban shapes 
that minimise contact with wildland, integrating interfaces into the town planning operation, and designing them as functions where maintenance is ensured (recreational parks, golf courses) (Lévy \& Broussus 2007) (Fig. 6).

Actions to mitigate risk in interface areas focus mainly on plot and building treatment. The aim of most experimental research and analysis of how built-up areas are affected during important events is to assess the behaviour of structures during a fire event, and in particular to check how they resist different propagation modes (radiant heat, flying embers). The conclusions obtained from these studies have been incorporated into various building regulations (materials, structural design) and surrounding complementary facilities (internal gardens, types of plot enclosure).

The official building licence is the tool used to check that new buildings comply with current legislation, generic (urban and building codes) and specific planning regulations for the treatment of particularly sensitive high wildfire risk areas.

\subsection{Mitigation techniques for treating the existing situation}

Although in exceptional cases proposals have been made to transfer population out of exceptionally high risk areas (recommended by the Victorian Bushfires Royal Commission after the catastrophic events of 2009 in Australia), the response of public bodies, rather than attempting to halt this WUI expansion process, has been to act on fuels, controlling or reducing them to solve the problem, and to promote better preparedness of the communities who live in these vulnerable zones.

This view of damage mitigation requires raising awareness of people living in risk-prone areas to an appropriate level. Attempts have been made to involve owners and communities as directly responsible for adapting their homes to the existing hazard conditions, within a broader approach based on the roll-out of self-protection mechanisms. Many handbooks, guidelines, and recommendations coincide on some concepts, classifying the recommended treatment of structures and vegetable fuels, to reduce vulnerability and improve defences. The key concept is a defensible space: the firebreak area between a structure and fire, which in normal conditions creates a safe area to reduce or stop the fire spreading towards the structure (by direct flames or radiant heat) (Fig. 5).

On the other hand, mandatory clearing of a security buffer zones of varying width around residential developments to reduce fire intensity is commonplace in these areas. This may be included in forest or fire protection regulations or in the Building Code (Galiana, 2012). 
Box 2. Reducing wildfire intensity in the WUI (forest fuel management): risk management strategies - best practice

General information. Pla de Prevenció en Urbanizacions (PPU) (Provincia de Barcelona, Catalonia, Spain) (2003- ) http://www.diba.cat/web/incendis/prevencio/ppu

Description. Funding, technical and administrative support for compliance with WUI management legislation (Ley 5/2003, 22th April): i) establish a perimeter protection strip at least $25 \mathrm{~m}$ wide with reduced timberline and cleared shrub stratum; ii) keep inner non-built plots clear of dry vegetation; iii) maintain network of approved water points; iv) draft a selfprotection plan; v) ensure access roads and ditches are free of vegetation.

In almost all cases, local council has subsidiary responsibility for implementing the measures.

Local councils do not have the technical and financial resources to implement these preventive measures. The Diputació de Barcelona drafted the 2004 Pla de Prevenció en Urbanizacions (PPU) (Plan for prevention of forest fires in housing developments) to provide municipal authorities with the technical documentation needed to implement effective preventive measures included in the legislation.

Each development has its plan. Drafting the PPU starts with the signing of a cooperation agreement between local council and Diputació de Barcelona. Diputació de Barcelona provides the local council with technical and administrative support to help with the administrative procedures required. The Generalitat de Catalunya offers financial support to finance compliance with Ley 5/2003, to create a buffer zone around the development.

Effects. a) General vegetation treatment in the immediate vicinity of housing developments; b) Progress in the safety of treated urban areas; c) Reduction of uncontrolled dumping of waste in the WUI; d) Information supplied to inhabitants involving them in the WUI vegetation clearing process, requiring them to pay a small part of the operational cost; e) Involvement of local councils in fire prevention linked to urban development.

Evaluation. High transferability. Generic weaknesses: home owners do not directly assume responsibility for treatment of peripheral buffer zones and local authorities are responsible; maintenance costs are mainly paid from public funds; permanence of the process is not guaranteed.
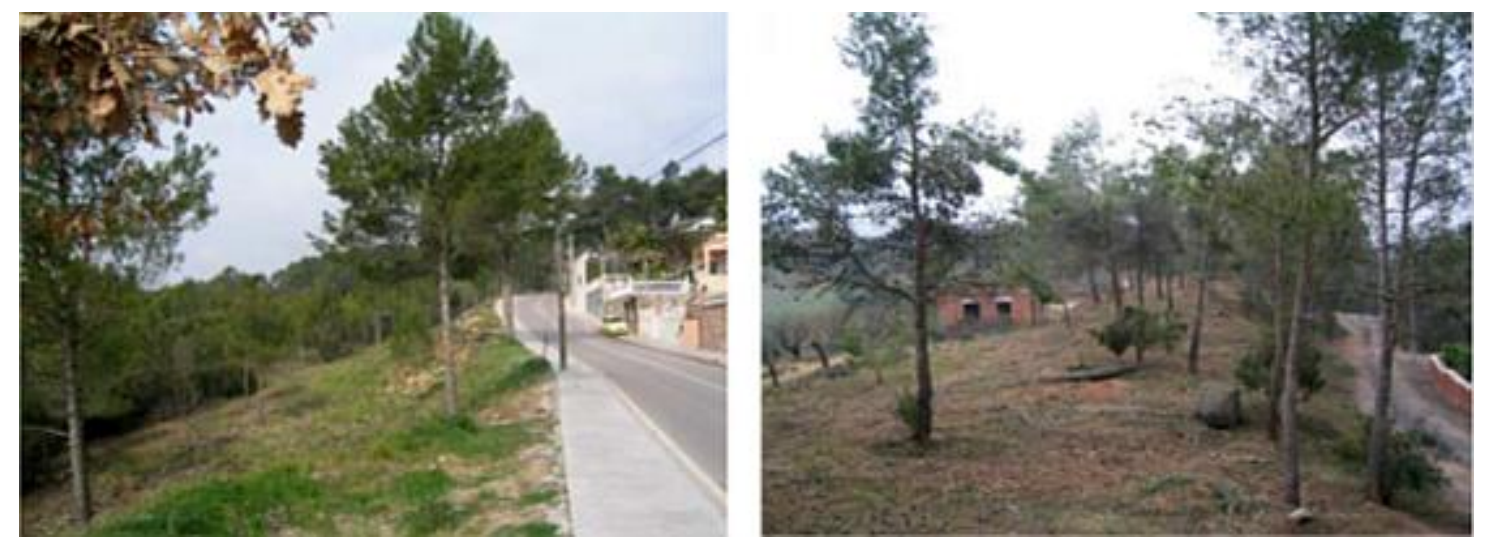

Left: Perimeter strip maintained bi-annually with Pinus Nigra and Quercus Faginea. Right: Vegetation treatment in green areas. 50-year old Pinus Halepensis (Terés et al. 2007)

Documentation. Cataleg de Serveix. Obertura de la franja perimetral en nuclis de població a la interficie urbana forestal http://cataleg2016cercador.diba.cat/fitxa?id=16149\&WPag=1 


\section{Conclusions}

There is consensus that WUI expansion is the most influential dynamic in the context of increasing vulnerability to forest fires in European countries in the Mediterranean basin. Increasing urban development in contact with forested zones causes more ignition events. The fires affecting these developed zones may turn into very complex emergencies for the extinction crews (with mass evacuations and many different buildings to be defended simultaneously), and often exceed their response capacity.

To date, risk management has been markedly reactive, focused on reinforcing extinction systems to obtain immediate results. Although there has been important investment in recent years, the problem is becoming increasingly acute, and the number and complexity of the urban-forest fire episodes continues to grow. In this situation, discourses are emerging from different viewpoints, defining practices which defend the need to advance towards a coexistence with fire. Faced with the inevitability of fires, what must be achieved is lower vulnerability to them, by devising long-term strategies which help to mitigate the problem.

To reduce vulnerability fire risk must be included in land-use planning practice at different spatial scales. The questions which must be asked include which zones should be developed and which not; how this development should take place; and how the buildings should be designed. These questions of 'placing and shaping' can and should be approached from land-use planning. However, action has not progressed beyond treatment of built structures, plots and their surrounding areas, and there are few genuinely proactive approaches.

The reasons for this are complex. The inclusion of the WUI concept from other cultures (US, Australia) was implemented without sufficient adaptation to the European status quo. The same occurred with the approaches to the problem, defined from cultural positions in which imposing restrictions on building development is an exception. This is not the case in Mediterranean Europe, where there is general acceptance of restrictions on the right to build for environmental reasons. However, in contrast to other risks (e.g. flooding) which are fully integrated, urban planning does not include forest fire risk. Political barriers are strengthened by the rejection of the technical experts, many of whom are not ready to implement wildfire management through planning controls, and in short, are not trained in fire behaviour science.

The main aim in treatment and adaptation of existing situation is damage mitigation. Most interventions deal with scattered residential developments in forest areas and include: perimeter protective buffer strips to reduce wildfire intensity, self-protection plans and guidelines on good practice for plot management. Specific objectives include: to reduce the vulnerability of homes in the WUI; to spread risk reduction from urban developments to wildland areas; to make firefighter intervention easier and safer.

The WUI problem continues to be associated almost exclusively with forest fires. Thus, intervention is focused mainly on initiatives taken by forest and fire managers. These initiatives are mostly linked to technical services which encourage a high level of voluntary participation, but are largely unconnected with other areas or with the wider public. The role of official bodies is essential to provide funding, technical and administrative support. The management and processing at each stage of the administrative procedures needed to implement the planned measures is expensive because concerted efforts are required to convince public opinion. Home owners do not assume direct responsibility for the treatment of the peripheral WUI zones, as this is the responsibility of the authorities and the cost of the work largely depends on public funds.

Initiatives to increase public awareness focus on intervention in well-defined communities located in the WUI zones including technical information sessions individually addressed to housing development residents and house-to-house distribution of a manual of self-protection measures in the event of forest fire. There is, however, no general awareness of the problem in other interest groups (citizens, councillors, town planners and other spatial managers). Increased awareness of the need to coordinate planning, forestry and civil protection procedures is essential, with official coordination of urban planning, forestry and environmental codes, to promote voluntary or mandatory management actions in WUI. 


\section{Acknowledgements}

The author acknowledges the productive discussions hosted in the Project MedWildFireLab (Global Change Impacts on Wildland Fire Behaviour and Uses in Mediterranean Forest Ecosystems, towards a «wall less» Mediterranean Wildland Fire Laboratory) funded by ERANET FORESTERRA, and their financial support.

\section{Academic references}

[1] Bakker, M. \& Veldkamp, A. (2012). Changing relationships between land use and environmental characteristics and their consequences for spatially explicit land-use change prediction. Journal of Land Use Science 7(4), 407-424. DOI: $10.1080 / 1747423 X .2011 .595833$.

[2] Bar Massada, A., Radeloff, V. C. \& Stewart, S. I. (2011). Allocating fuel breaks to optimally protect structures in the wildland-urban interface. International Journal of Wildland Fire, 20(1), 59-68.

[3] Bardsley, D. K., Weber, D., Robinson, G. M., Moskwa, E. \& Bardsley, A. M. (2015). Wildfire risk, biodiversity and peri-urban planning in the Mt Lofty Ranges, South Australia. Applied Geography, 63, 155-165. DOI: 10.1016/j.apgeog.2015.06.012.

[4] Bond, T. \& Mercer, D. (2014). Subdivision Policy and Planning for Bushfire Defence: A Natural Hazard Mitigation Strategy for Residential Peri-Urban Regions in Victoria, Australia. Geographical Research, 52(1), 6-22. DOI: 10.1111/1745-5871.12040.

[5] Bouisset, C. (2011). PPR, urbanisation et risques d'incendie de forêt dans les PyrénéesOrientales: méthodes, enjeux, débats. Cybergeo: European Journal of Geography. DOI: 10.4000/cybergeo.24658.

[6] Butsic, V., Syphard, A. D., Keeley, J. E. \& Bar-Massada, A. (2017). Can private land conservation reduce wildfire risk to homes? A case study in San Diego County, California, USA. Landscape Und Urban Planning, 157, 161-169. DOI: 10.1016/j.landurbplan.2016.05.002.

[7] Buxton, M., Haynes, R., Mercer, D. \& Butt, A. (2011). Vulnerability to bushfire risk at Melbourne's urban fringe: the failure of regulatory land use planning. Geographical Research, 49(1), 1-12. DOI: 10.1111/j.1745-5871.2010.00670.x.

[8] Calkin, D. E., Cohen, J. D., Finney, M. A. \& Thompson, M. P. (2014). How risk management can prevent future wildfire disasters in the wildland-urban interface. Proceedings of the National Academy of Sciences, 111(2): 746-751. DOI: 10.1073/pnas.1315088111.

[9] Castillo Soto, M. E. (2012). The identification and assessment of areas at risk of forest fire using fuzzy methodology. Applied Geography, 35(1), DOI: 10.1016/j.apgeog.2012.07.001.

[10] Cohen, J. (2010). The wildland-urban interface fire problem. Fremontia, 38(2-3), 16-22.

[11] Colburn, J. E. (2008). The fire next time: Land use planning in the wildland/urban interface. Journal of Land, Resources \& Environmental Law, 28(2), 223-256. DOI: 10.2139/ssrn.1106617.

[12] Cova, T. J. (2005). Public safety in the urban-wildland interface: should fire-prone communities have a maximum occupancy? Natural Hazards Review, 6(3), 99-108. DOI: 10.1061/(ASCE) 1527-6988(2005)6:3(99).

[13] Cova, T. J., Theobald, D. M., Norman III, J. B. \& Siebeneck, L. K. (2013). Mapping wildfire evacuation vulnerability in the western US: the limits of infrastructure. GeoJournal, 78(2), 273-285. DOI: 10.1007/s10708-011-9419-5. 
[14] Elia, M., Lafortezza, R., Colangelo, G. \& Sanesi, G. (2014). A streamlined approach for the spatial allocation of fuel removals in wildland-urban interfaces. Landscape Ecology, 29(10), 1771-1784. DOI: 10.1007/s10980-014-0070-7.

[15] Fischer, A. P., Spies, T. A., Steelman, T. A., Moseley, C., Johnson, B. R., Bailey, J. D., Ager, A. A., Bourgeron, P., Chainley, S., Collins, B. M., Kline, J. D., Leahy, J. E., Littell, J. S., Millington, J. D. A., Nielson-Pincus, M., Olsen, C. S., Paveglio, T. B., Roos, C. I., SteenAdams, M. M., Stevens, F. R., Vukomanovic, J., White, E. M. \& Bowman, D. M. J. S. (2016). Wildfire risk as a socioecological pathology. Frontiers in Ecology and the Environment, 14(5): 276-284. DOI: 10.1002/fee.1283.

[16] Galiana Martín, L. (2012). Las interfaces urbano-forestales: un nuevo territorio de riesgo en España. Boletín de la Asociación de Geógrafos Españoles, 58, 205-226.

[17] Galiana-Martín, L. \& Karlsson, O. (2012). Development of a Methodology for the Assessment of Vulnerability Related to Wildland Fires Using a Multi-Criteria Evaluation. Geographical Research, 50(3), 304-319. DOI: 10.1111/j.1745-5871.2011.00718.x.

[18] Haight, R. G., Cleland, D. T., Hammer, R. B., Radeloff, V. C. \& Rupp, T. S. (2004). Assessing fire risk in the wildland-urban interface. Journal of Forestry, 102(7), 41-48.

[19] Holland, M., March, A., Yu, J. \& Jenkins, A. (2013). Land use planning and bushfire risk: CFA referrals and the February 2009 Victorian fire area. Urban Policy and Research 31(1), 4154. DOI: 10.1080/08111146.2012.736255.

[20] Hughes, R. \& Mercer, D. (2009). Planning to reduce risk: the wildfire management overlay in Victoria, Australia. Geographical Research, 47(2), 124-141. DOI: 10.1111/j.17455871.2008.00556.x.

[21] Indovina, F. (2007). La ciudad de baja densidad: lógicas, gestión y contención. Barcelona: Diputació.

[22] Kennedy, M. C. \& Johnson, M. C. (2014). Fuel treatment prescriptions alter spatial patterns of fire severity around the wildland-urban interface during the Wallow Fire, Arizona, USA. Forest Ecology and Management, 318, 122-132. DOI: 10.1016/j.foreco.2014.01.014.

[23] Lafortezza, R., Tanentzap, A. J., Elia, M., John, R., Sanesi, G. \& Chen, J. (2015). Prioritizing fuel management in urban interfaces threatened by wildfires. Ecological Indicators, 48, 342347. DOI: 10.1016/j.ecolind.2014.08.034.

[24] Lein, J. K. \& Stump, N. I. (2009). Assessing wildfire potential within the wildland-urban interface: a southeastern Ohio example. Applied Geography, 29(1), 21-34. DOI: $10.1016 /$ j.apgeog.2008.06.002.

[25] Martínez, J., Vega-García, C. \& Chuvieco, E. (2009). Human-caused wildfire risk rating for prevention planning in Spain. Journal of Environmental Management, 90(2), 1241-1252. DOI: 10.1016/j.jenvman.2008.07.005.

[26] Mell, W. E., Manzello, S. L., Maranghides, A., Butry, D. \& Rehm, R. G. (2010). The wildlandurban interface fire problem-current approaches and research needs. International Journal of Wildland Fire, 19(2), 238-251. DOI: 10.1071/WF07131.

[27] Moreira, F., Viedma, O., Arianoutsou, M., Curt, T., Koutsias, N., Rigolot, E., ... \& Mouillot, F. (2011). Landscape-wildfire interactions in southern Europe: implications for landscape management. Journal of Environmental Management, 92(10), $\frac{2389-2402 .}{2}$ DOI: $10.1016 /$ j.jenvman.2011.06.028.

[28] Moreno, M. V., Conedera, M., Chuvieco, E. \& Pezzatti, G. B. (2014). Fire regime changes and major driving forces in Spain from 1968 to 2010. Environmental Science \& Policy, 37, 11-22. DOI: 10.1016/j.envsci.2013.08.005.

[29] Moritz, M. A. \& Stephens, S. L. (2008). Fire and sustainability: considerations for California's altered future climate. Climatic Change, 87(1), 265-271. DOI: 10.1007/s10584-007-9361-1. 
[30] Moritz, M. A., Batllori, E., Bradstock, R. A., Gill, A. M., Handmer, J., Hessburg, P. F., Leonard, J., McCaffrey, S., Odion, D. C., Schoennagel, T. \& Syphard, A. D. (2014). Learning to coexist with wildfire. Nature, 515 (7525): 58-66. DOI: 10.1038/nature13946.

[31] Paveglio, T. B., Prato, T. \& Hardy, M. (2013). Simulating effects of land use policies on extent of the wildland urban interface and wildfire risk in Flathead County, Montana. Journal of Environmental Management, 130, 20-31. DOI: 10.1016/j.jenvman.2013.08.036.

[32] Pincetl, S., Rundel, P. W., De Blasio, J. C., Silver, D., Scott, T., Keeley, J. E. \& Halsey, R. (2008). It's the land use, not the fuels: fires and land development in southern California. Real Estate Review, 37(1), 25.

[33] Platt, R. V. (2014). Wildfire hazard in the home ignition zone: An object-oriented analysis integrating LiDAR and VHR satellite imagery. Applied Geography, 51, 108-117. DOI: $10.1016 /$ j.apgeog.2014.03.011.

[34] Price, O. F., Borah, R., Bradstock, R. \& Penman, T. (2015). An empirical wildfire risk analysis: the probability of a fire spreading to the urban interface in Sydney, Australia. International Journal of Wildland Fire, 24, 597-606. DOI: 10.1071/WF14160.

[35] Smith, A. M., Kolden, C. A., Paveglio, T. B., Cochrane, M. A., Bowman, D. M., Moritz, M. A., Kliskey, A. D., Alessa, L., Hudak, A. T., Hoffman, C. M., Lutz, J. A., Queen, L. P., Goetz, S. J., Higueras, P. E., Boschetti, L., Flannigan, M., Yedinak, K. M., Watts, A. C., Strand, E. K., van Wagtendonk, J. W., Anderson, S. W., Stock, B. J. \& Abatzoglou, J. T. (2016). The science of firescapes: achieving fire-resilient communities. Bioscience, 66(2), 130-146. DOI: 10.1093/biosci/biv182.

[36] Stockmann, K., Burchfield, J., Calkin, D. \& Venn, T. (2010). Guiding preventative wildland fire mitigation policy and decisions with an economic modelling system. Forest Policy and Economics, 12(2), 147-154. DOI: 10.1016/j.forpol.2009.09.009.

[37] Syphard, A. D., Massada, A. B., Butsic, V. \& Keeley, J. E. (2013). Land use planning and wildfire: development policies influence future probability of housing loss. PLOS ONE, 8(8), e71708. DOI: 10.1371/journal.pone.0071708.

[38] Terés, J. A., LLaquet, J., Tudela, A. \& Canyameres, E. (2007). El tratamiento de la vegetación para la prevención de incendios forestales en la interfaz urbano-forestal en Catalunya. In Actas de la IV Conferencia Internacional de Incendios Forestales, Sevilla (España), 13-18 de mayo de 2007. Madrid: Ministerio de Medio Ambiente.

[39] Viedma, O., Moity, N. \& Moreno, J. M. (2015). Changes in landscape fire-hazard during the second half of the $20^{\text {th }}$ century: Agriculture abandonment and the changing role of driving factors. Agriculture, Ecosystems \& Environment, 207, 126-140. DOI: 10.1016/j.agee.2015.04.011.

Other sources

[40] EEA (European Environment Agency) (2016). Urban sprawl in Europe. Joint EEA-FOEN report. EEA Report, $\mathrm{n}^{\circ} 11 / 2016$.

[41] Lévy, B. \& Broussus, D. (2007). Prise en compte du risque "feu de forêt" dans les opérations d'áménagement. Conseil d'Architecture, d'Urbanisme et de I'Environnement du Gard. 